\title{
Historical changes in land use influence current habitat preferences of large herbivores
}

\author{
Kajetan Perzanowski $\cdot$ Maciej Januszczak $\cdot$ Rafał Lopucki 1
}

Received: 13 March 2019/Accepted: 3 September 2019/Published online: 12 September 2019

(C) The Author(s) 2019

\begin{abstract}
Context Predicting habitat use patterns is a key issue in the management of large herbivore populations. Particularly, indicators providing a model of the spatial distribution of a population in a simple way, without the necessity of laborious field research, are still being sought. Analysis of historical landscape changes can be one of such predictive tools.

Objectives We tested the hypothesis that historical changes in land use can be used as an effective factor enabling prediction of spatial distribution. As a case study, data on habitat preferences of European bison Bison bonasus (wisents) were used.

Methods Spatial distribution of 17302 records of the presence of wisents, collected over the period of 10 years, was compared using contemporary and historical habitat maps for the Bieszczady Mts.
\end{abstract}

K. Perzanowski · R. Łopucki ( $\square)$

Centre for Interdisciplinary Research, Institute of

Landscape Architecture, The John Paul II Catholic

University of Lublin, Konstantynów 1H, 1J,

20-708 Lublin, Poland

e-mail: lopucki@kul.pl

K. Perzanowski

e-mail: kajetan.perzanowski@kul.pl

M. Januszczak

Museum and Institute of Zoology PAS, Carpathian

Wildlife Research Station, Ogrodowa 10,

38-700 Ustrzyki Dolne, Poland

e-mail: pertlibec@wp.pl
(Poland). The area of approx. 87 thousand ha was selected, where the density of human population decreased over four times, and the percentage of forests increased from over $30 \%$ to almost $80 \%$ due to land abandonment.

Results Wisents were recorded significantly more frequently in parts of the forest that in the past were used for agriculture. We found that identification of parts of the forest overgrowing former cultivated fields makes it possible to predict the spatial distribution of wisent herds with very high probability.

Conclusions Information on historical changes in land use can be used as a simple and effective factor enabling prediction of habitat selection by wisents. Such an approach can potentially be useful for similar assessments of other large wild herbivores.

Keywords Wisents Habitat preference $\cdot$ Land use patterns $\cdot$ Historical changes

\section{Introduction}

Changes in forest cover are among the most distinct effects of human activity on the environment. In the past, these changes were mainly related to deforestation when areas with most fertile soils and best climatic conditions were converted into agriculture (Iverson 1988; Wulf et al. 2010). However, in Europe, 
in the last few decades, a new trend has appeared-an increase of forest cover as a result of spontaneous or planned reforestation in areas abandoned by agriculture or due to termination of other activities e.g. former military training grounds (Bowen et al. 2007; Falcucci et al. 2007; Feranec et al. 2010; Estel et al. 2015; Zgłobicki et al. 2016).

These changes in the landscape have had an effect on forest large herbivores (Gordon 2009). In a situation where forests cover the least agriculturally suitable parts of the continent (Wulf et al. 2010) the forest wildlife is forced to occur at sites with poor soils. This in turn, determines the abundance and quality of available plants, which is particularly important for herbivores being directly dependent upon the availability and properties of their food base, and therefore sensitive to decrease of carrying capacity of their home ranges (Dimbleby 1984; Drent and Prins 1987; Birks et al. 1999; Vera 2000). The very well known phenomenon of many ungulate species frequenting agricultural crops, where they can find plentiful and much more nutritious food than in the forest or uncultivated meadows, is also a direct consequence of this historical process (Drent and Prins 1987; Putman 1988; Hofman-Kamińska and Kowalczyk 2012; Klich et al. 2018). However, when the agricultural land is reforested, it can be expected then that animals having an access to forest stands growing in sites adequate for agriculture, would prefer them over other parts of forested areas. Proving the occurrence of such a phenomenon may help in predicting habitat use patterns of large herbivores and facilitate the management of their populations.

The possibility of testing such a hypothesis is offered by the Bieszczady Mountains (south-eastern Poland), because this region, once quite densely populated, some 70 years ago was deprived of a majority of local inhabitants, and a large part of formerly cultivated land was reforested intentionally or due to natural succession (Augustyn 2004). This

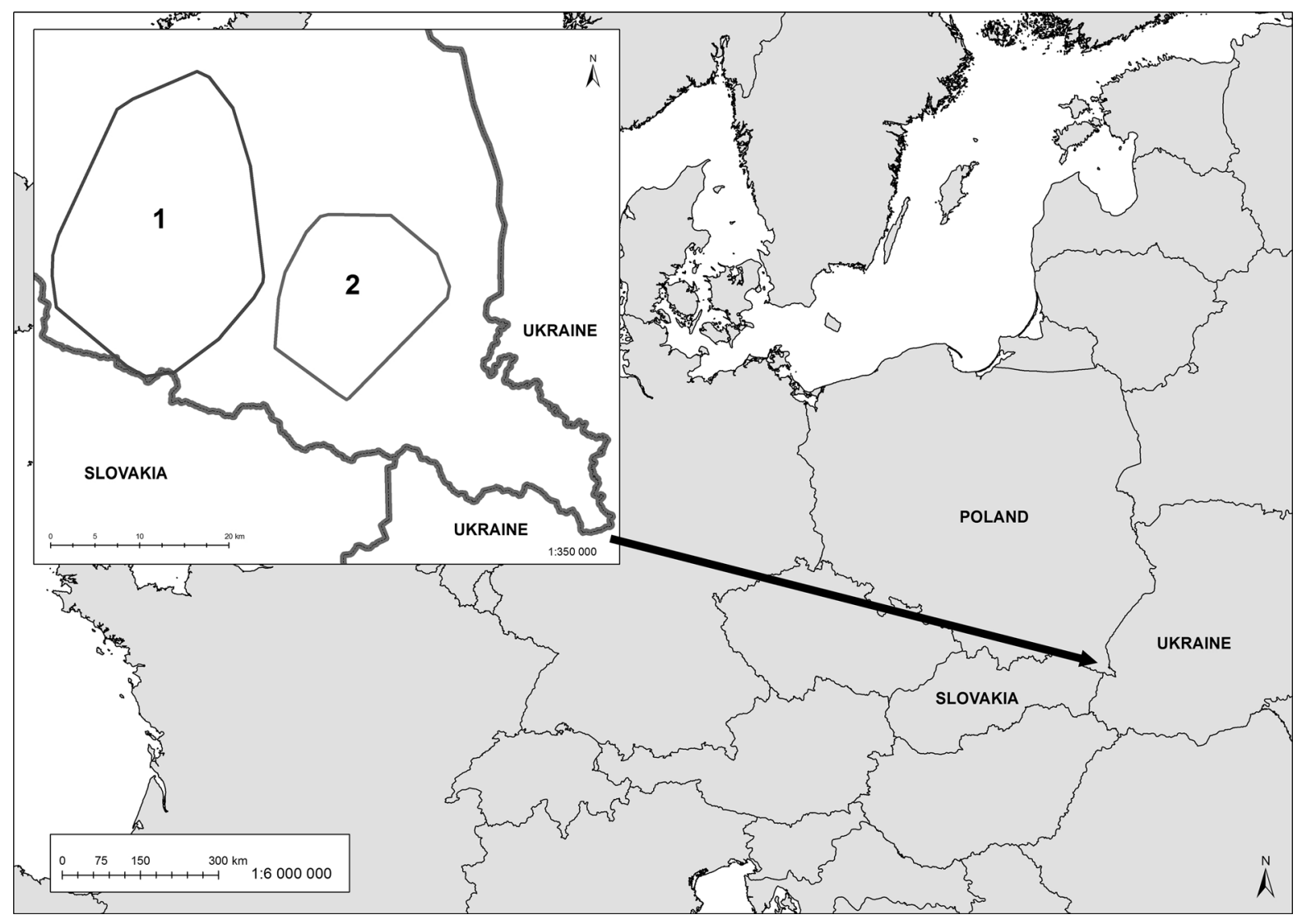

Fig. 1 Localisation of the study area and home ranges of both considered wisent subpopulations in Bieszczady Mountains: (1) western (so called Baligród herd), (2) eastern (so called Tworylne herd) 
Table 1 Data set used for analysis of the effect of historical changes in land use on the habitat preferences of wisents in the Bieszczady Mountains, Poland

\begin{tabular}{|c|c|c|c|c|c|}
\hline & Season & $\begin{array}{l}\text { Type of } \\
\text { analysed area }\end{array}$ & $\begin{array}{l}\text { Changes in land use: } \\
\text { (Prior } \rightarrow \text { present) }\end{array}$ & $\begin{array}{l}\text { Area } \\
\text { [ha] }\end{array}$ & $\begin{array}{l}\text { No of records of wisents' } \\
\text { presence (received) }\end{array}$ \\
\hline \multirow[t]{24}{*}{ Western subpopulation } & \multirow[t]{12}{*}{ Summer } & \multirow[t]{4}{*}{$\mathrm{MCP}$} & Forest $\rightarrow$ open & 397 & 47 \\
\hline & & & Forest $\rightarrow$ forest & 22923 & 3284 \\
\hline & & & Open $\rightarrow$ forest & 17338.46 & 2947 \\
\hline & & & Open $\rightarrow$ open & 14509.54 & 386 \\
\hline & & \multirow[t]{4}{*}{ Kernel 95} & Forest $\rightarrow$ open & 80.73 & 47 \\
\hline & & & Forest $\rightarrow$ forest & 10671.11 & 3047 \\
\hline & & & Open $\rightarrow$ forest & 5857.48 & 2715 \\
\hline & & & Open $\rightarrow$ open & 2156.71 & 340 \\
\hline & & \multirow[t]{4}{*}{ Kernel 50} & Forest $\rightarrow$ open & 2.72 & 25 \\
\hline & & & Forest $\rightarrow$ forest & 883.20 & 894 \\
\hline & & & Open $\rightarrow$ forest & 875.72 & 1215 \\
\hline & & & Open $\rightarrow$ open & 142.29 & 152 \\
\hline & \multirow[t]{12}{*}{ Winter } & \multirow[t]{4}{*}{ MCP } & Forest $\rightarrow$ open & 433.34 & 28 \\
\hline & & & Forest $\rightarrow$ forest & 21941.83 & 1996 \\
\hline & & & Open $\rightarrow$ forest & 16714.39 & 2926 \\
\hline & & & Open $\rightarrow$ open & 14043.83 & 434 \\
\hline & & \multirow[t]{4}{*}{ Kernel 95} & Forest $\rightarrow$ open & 106.36 & 21 \\
\hline & & & Forest $\rightarrow$ forest & 4473.47 & 1745 \\
\hline & & & Open $\rightarrow$ forest & 4259.50 & 2639 \\
\hline & & & Open $\rightarrow$ open & 3269.46 & 376 \\
\hline & & \multirow[t]{4}{*}{ Kernel 50} & Forest $\rightarrow$ open & 2.89 & 2 \\
\hline & & & Forest $\rightarrow$ forest & 707.63 & 687 \\
\hline & & & Open $\rightarrow$ forest & 869.08 & 1280 \\
\hline & & & Open $\rightarrow$ open & 138.20 & 136 \\
\hline \multirow[t]{24}{*}{ Eastern subpopulation } & \multirow[t]{12}{*}{ Summer } & \multirow[t]{4}{*}{$\mathrm{MCP}$} & Forest $\rightarrow$ open & 71.82 & 4 \\
\hline & & & Forest $\rightarrow$ forest & 12485 & 844 \\
\hline & & & Open $\rightarrow$ forest & 12939.33 & 1806 \\
\hline & & & Open $\rightarrow$ open & 3860.74 & 310 \\
\hline & & \multirow[t]{4}{*}{ Kernel 95} & Forest $\rightarrow$ open & 8.45 & 4 \\
\hline & & & Forest $\rightarrow$ forest & 3141.58 & 731 \\
\hline & & & Open $\rightarrow$ forest & 3454.40 & 1654 \\
\hline & & & Open $\rightarrow$ open & 575.61 & 296 \\
\hline & & \multirow[t]{4}{*}{ Kernel 50} & Forest $\rightarrow$ open & 0.42 & 0 \\
\hline & & & Forest $\rightarrow$ forest & 33.98 & 33 \\
\hline & & & Open $\rightarrow$ forest & 463.80 & 675 \\
\hline & & & Open $\rightarrow$ open & 180.94 & 202 \\
\hline & \multirow[t]{12}{*}{ Winter } & \multirow[t]{4}{*}{$\mathrm{MCP}$} & Forest $\rightarrow$ open & 60.08 & 2 \\
\hline & & & Forest $\rightarrow$ forest & 11144 & 485 \\
\hline & & & Open $\rightarrow$ forest & 12013.16 & 1360 \\
\hline & & & Open $\rightarrow$ open & 3682.19 & 279 \\
\hline & & \multirow[t]{4}{*}{ Kernel 95} & Forest $\rightarrow$ open & 7.82 & 2 \\
\hline & & & Forest $\rightarrow$ forest & 1579.07 & 376 \\
\hline & & & Open $\rightarrow$ forest & 2916.94 & 1275 \\
\hline & & & Open $\rightarrow$ open & 414.87 & 267 \\
\hline & & \multirow[t]{4}{*}{ Kernel 50} & Forest $\rightarrow$ open & 1.01 & 0 \\
\hline & & & Forest $\rightarrow$ forest & 33.38 & 35 \\
\hline & & & Open $\rightarrow$ forest & 324.63 & 428 \\
\hline & & & Open $\rightarrow$ open & 142.85 & 196 \\
\hline
\end{tabular}


area is inhabited now by the world's largest mountain population of pure blood European bison (wisents) (approx. 500 individuals) reintroduced there 56 years ago (Augustyn 2004; Marszałek and Perzanowski 2018). In this paper we focus upon the question, whether parts of the forest growing now at former agricultural land are higher preferred by free ranging wisents, than stands which were never in the past converted into cultivated fields. The wisent seems to be a suitable species for testing hypothesis that the analysis of historical changes in land use can facilitate explanation of the spatial distribution of forest ungulates, as it: belongs to large herbivores (dependent on the fertility of habitats), its population density in Bieszczady is not excessively high (animals can freely select optimal habitats), the species is strictly protected and its population is carefully, routinely monitored (data on its distribution and occurrence are abundant and of high quality).

\section{Methods}

Data on historical land use changes and habitat preferences of the European bison were collected within the home range of the population of this species in the Bieszczady Mts. in the south-east of Poland (Fig. 1). Before 1939, the region was characterised by a low forest cover (32\%) and high human density of over 70 people $/ \mathrm{km}^{2}$. Nowadays, the forest cover is close to $80 \%$ and the human population is approx. 16 people $/ \mathrm{km}^{2}$ (Augustyn 2004; Statistical Office in Rzeszów 2018).

At present, population numbers of large herbivores, especially red deer, are very high in this area (Perzanowski and Gula 2002), and the Forest Service in this region is concerned about potential damage to commercial stands, hence the interest in reliable assessment of the spatial distribution and habitat preferences of these species. Such information is crucial not only for the effective management of game species but also for further sound conservation of strictly protected, largest herbivore there-the wisent.

The analysed area covered over 87,000 hectares. The wisent population there has already been monitored for almost 20 years by local foresters and scientists, and all signs of animals' presence (visual observations, tracks, faeces, feeding marks) are
Fig. 2 A comparison of the distribution of wisent occurrence records for two subpopulations: western $(\mathbf{a}, \mathbf{b})$ and eastern $(\mathbf{c}$, d) within their home ranges (MCP) (see Fig. 1), areas regarded as actually used (kernel 95\%) and concentration areas (kernel $50 \%$ ) with the extent of forests and open areas before 1939 (a, c) and at present (b, d). (1) records of wisent occurrence, (2) MCP, (3) kernel 95\%, (4) kernel 50\%, (5) settlements, (6) forests, (7) open areas, (8) roads

recorded in standard observational cards. In total, 17302 records of the presence of wisents were collected: 9715 during the vegetative seasons and 7587 during the winters of 2006-2016 (Table 1).

The forest cover prevailing until 1939 was obtained from ordnance maps of the Polish Military Geographical Institute (WIG) in a scale of 1:50000 and transformed into projection PUWG-92 (http://polski. mapywig.org/news.php). Vectorization of this layer was done with ArcView/ArcMap 9.2. We obtained information on the contemporary land cover from the CORINE Land Cover 2006 database (http://www.eea. europa.eu/data-and-maps/).

\section{Data analysis}

Available data were analysed in two steps. At first, one of data mining techniques, i.e. the association analysis (Tan et al. 2019) was applied in order to identify hidden relationships in the data set and indicate the course for the ultimate statistical analysis. We were looking for association rules (expressed in the form of implication $\mathrm{X} \rightarrow \mathrm{Y}$ ) in the habitat selection by wisents considering both the present characteristics of a site (forested or open area) and the type of habitat that prevailed there in the past. We asked about the probability for finding evidence of the presence of wisents in:

- Formerly open but presently forested area (Open $\rightarrow$ forest).

- Formerly forested but presently open area (Forest $\rightarrow$ open).

- Formerly and presently forested area (Forest $\rightarrow$ forest).

- Formerly and presently open area (Open $\rightarrow$ open).

Two association rule metrics were determined: 
(a)

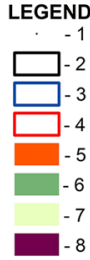

$\square-2$
-3
-4
-5
-6
-7
-8
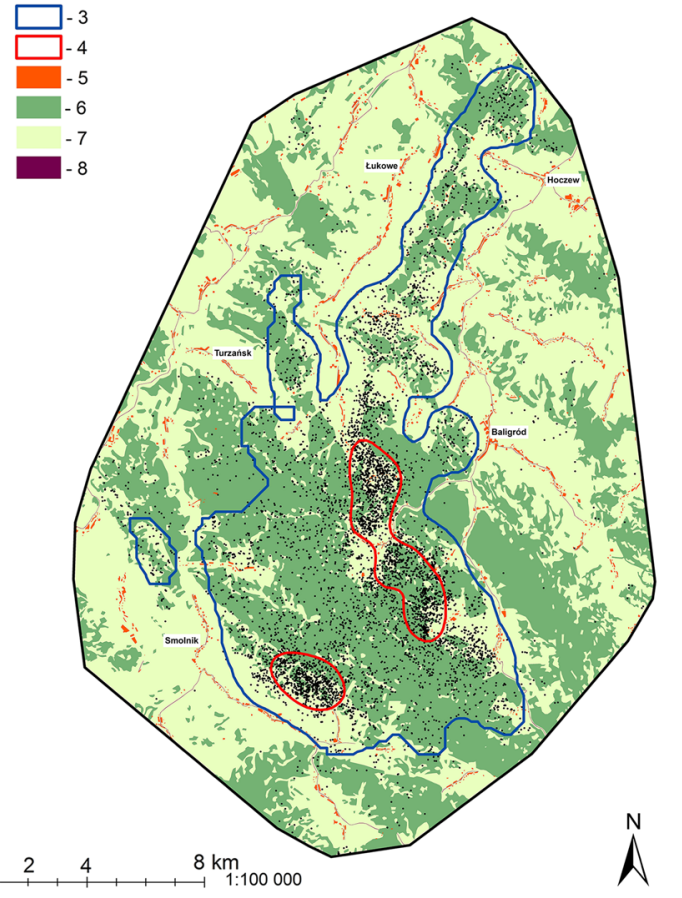

(c) LEGEND

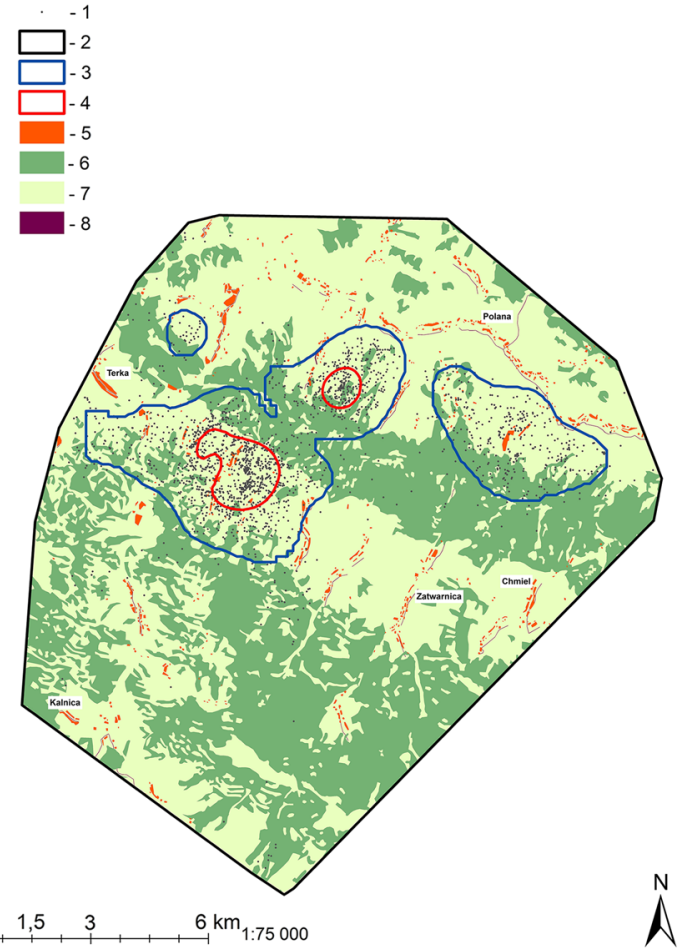

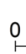

$\Lambda^{N}$ (b)

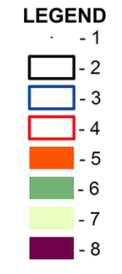

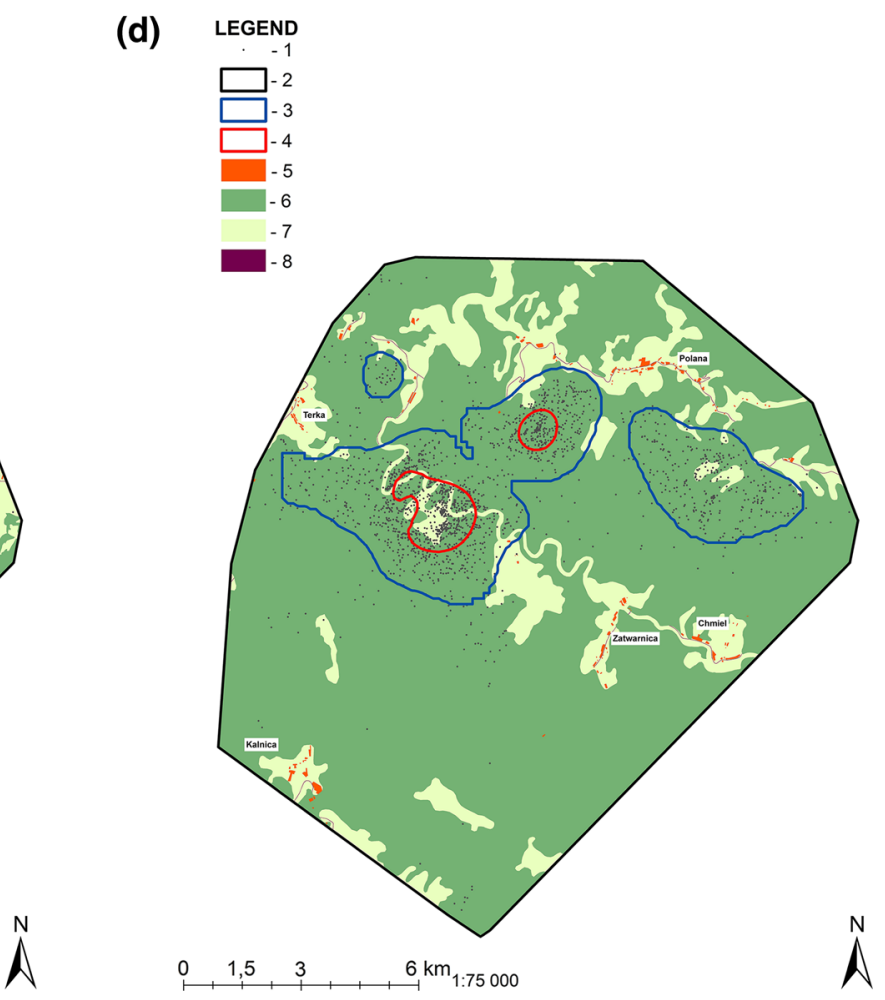


- Support: determines how often a rule is applicable to a given data (it is the percentage of events that contain the selected rule).

- Confidence: measures the reliability of the inference made by a rule and provides an estimate of the conditional probability of $\mathrm{Y}$ given $\mathrm{X}$. For a given rule $\mathrm{X} \rightarrow \mathrm{Y}$, the higher the confidence, the more likely it is for $\mathrm{Y}$ to be present in the event that contain X.

This analysis was performed separately for the whole area of the home ranges of wisent populations (MCP), the area assumed as actually used (kernel $95 \%$ ), and for the areas of concentration of wisents (kernel 50\%) (Table 1) (Fig. 2). The values of the frequency of the occurrence of wisents in a given habitat category were obtained during field research. Expected values were calculated on the basis of the proportion of the area of particular habitat categories within wisent home ranges.

During the second step, only the strongest relationships indicated by the association analysis (i.e. with the highest values of support and confidence metrics) were analysed statistically. The Chi square test for a $2 \times 2$ contingency table was used for this purpose. The origin of the empirical and expected values was the same as in the earlier analysis.

The analysis was performed using Statistica software (version 13.1, Dell Inc.).

\section{Results}

The results of the association analysis show that, for the Open $\rightarrow$ forest relationship, the values of the support index for the received data exceed the values of this parameter for the expected data in every case (for populations, seasons, and all methods of home area estimation) (Table 2). This indicates an existence of a rule that wisents more often (than could be expected) occur in areas that now are covered by the forest but used to be open in the past. The Forest $\rightarrow$ forest relationship is opposite: in a majority of cases, the values of the support index for the received data are lower than for the expected data. This indicates that wisents less frequently than could be expected occur in areas that were forested in the past and remain forested now. The high confidence index values confirm the reliability of these rules. For the third analysed Open $\rightarrow$ open implication, the values of support and confidence indexes do not reflect any clear relationship (Table 2).

Because the association analysis did not confirm any clear relationship for the Open $\rightarrow$ open implication (Table 2), and the Forest $\rightarrow$ open implication was very rare (Table 1), in the second step only records of the presence of wisents from currently forested areas were analysed (i.e. Open $\rightarrow$ forest and Forest $\rightarrow$ forest implications). Data presented in Fig. 3 show clear preference of wisents towards forests that used to be open areas in the past. For both populations and seasons, the actual numbers of the records of wisent occurrence in such habitats were significantly higher than their expected values. Such a tendency was observed for all methods of home area estimation.

\section{Discussion}

The results of our study confirm the hypothesis that the analysis of historical changes in land use can considerably facilitate explanation of the contemporary spatial distribution of large herbivores: wisents clearly preferred forests that had replaced former cultivated fields. This phenomenon is probably a simultaneous effect of a number of environmental factors among which soil fertility, i.e. a more nutritive food base, is probably the most important determinant.

Earlier studies on wisent population of Bieszczady Mountains (Kuemmerle et al. 2010; Perzanowski et al. 2011; Wołoszyn-Gałęza et al. 2016; Ziółkowska et al. 2016; Kuemmerle et al. 2018) revealed an influence of many various factors upon the distribution of their herds and habitat selection. That included both: natural features like the type and composition of forest stands, accessibility of open grasslands suitable for grazing, elevation above sea level, steepness and exposition of slopes, and the anthropogenic influence connected with proximity of settlements and traffic volume. The occurrence of wisents was negatively correlated with all human related factors. Among components of natural environment, the strongest positive influence upon the presence of wisents was found for open areas suitable for grazing as well as for tree stands with broken type of tree canopy, and especially in winter, so called secondary forest stands dominated by Scotch pine and alder, with rich ground flora of brambles. However, the 


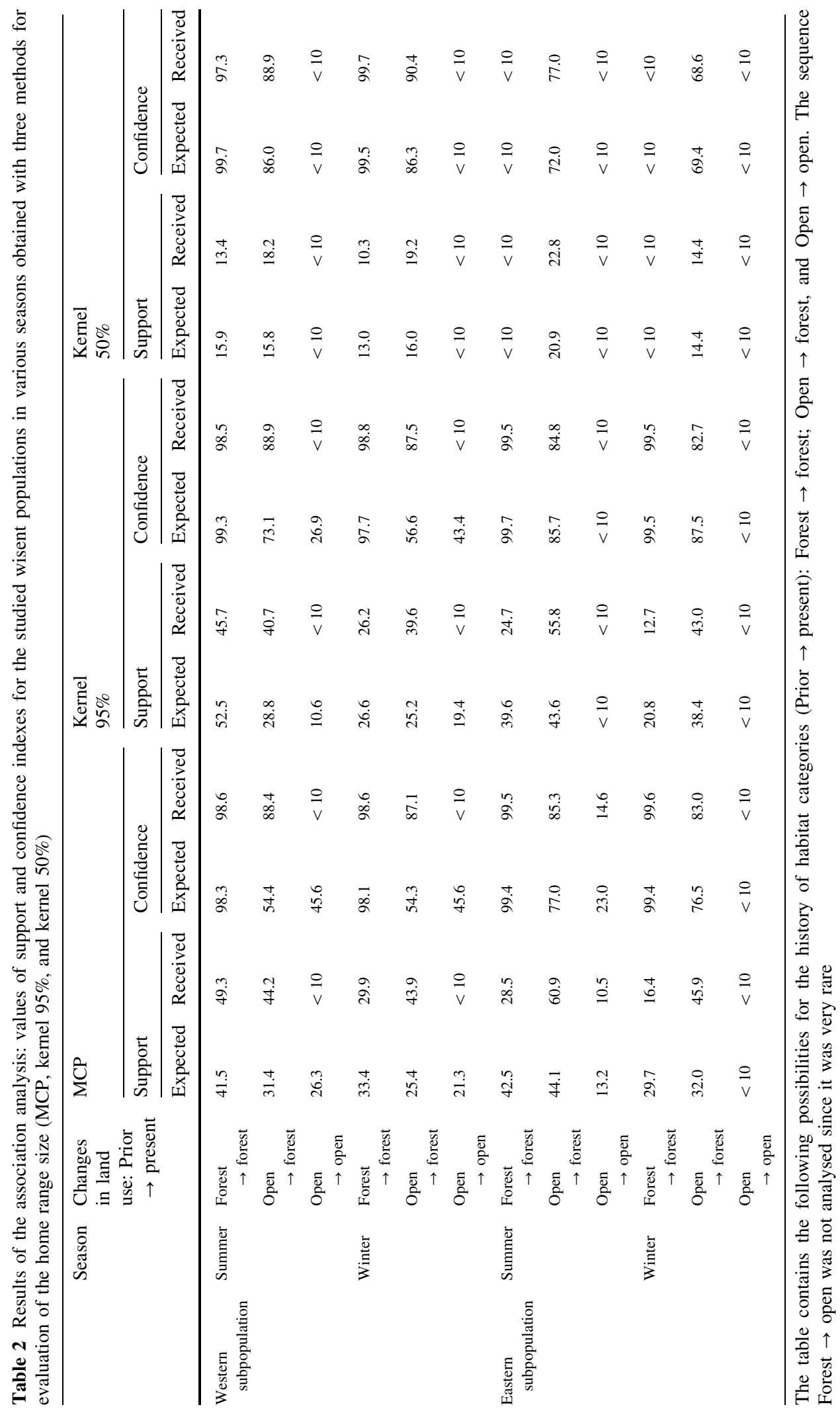




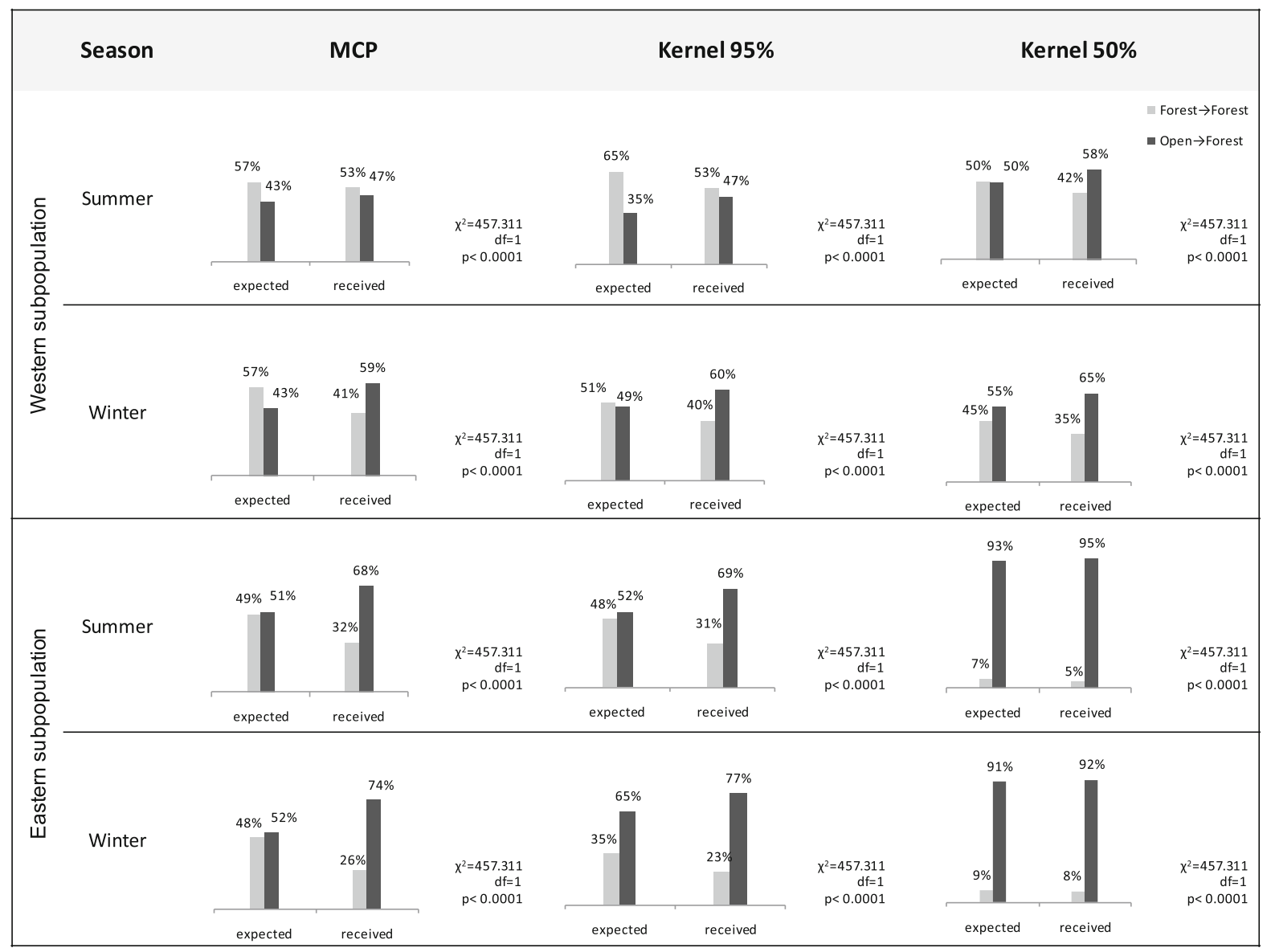

Fig. 3 Results of $\chi^{2}$ test: a comparison of expected and obtained values for the records of presence of wisents within areas that used to be open and are now forested (Open $\rightarrow$ Forest) with areas that were forested in the past and remain such now (Forest $\rightarrow$ Forest)

heterogeneous pattern of the spatial distribution of bison was not explicitly explained by the environmental factors considered so far.

The factor analysed in this paper, i.e. the fact whether a given forested area was used for farming in the past, may prove very useful for predicting the spatial distribution of large herbivores for several reasons. Firstly, it is very easy for classification, because it can be analysed in a binary scale where only two options (forest $\rightarrow$ forest and open areas $\rightarrow$ forest) are considered. Secondly, data for such analysis can be obtained very easily, as only an access to historical and contemporary maps is required. Thirdly, this factor merges a number of other aspects, e.g. soil fertility, characteristics of the microclimate, composition of local flora etc., which evaluation requires a number of assessments with various techniques. Therefore, using this factor as a principal indicator provides a model of the spatial distribution of a population in a simple way, without the necessity of laborious field research. As demonstrated in our results, while considering only this factor, it is possible to predict the spatial distribution of wisents with very high probability, since their tendency to prefer among available forest stands those growing at former agricultural land concerns as well whole home ranges as their areas of concentration. Moreover, our results suggest that stronger preference towards secondary forests may occur in winter (higher Chi square test values obtained for MCP in the winter season), which would confirm our expectations, since the higher quality and abundance of food available at former agricultural areas may be more important in this season than in summer.

Summarizing, information on historical changes in land use can be used as a simple and effective factor 
enabling prediction of habitat selection by wisents. Further investigations are needed to prove whether this approach can also be useful for other large wild herbivores. Results of this study may be useful in assessing the potential value of formerly abandoned lands for rewilding and reintroduction programs (Ceausu et al. 2015).

Acknowledgements The study is based on the results of the project "Continuous monitoring of wisent population in Bieszczady Mts." supported by the Regional Directorate of State Forests at Krosno.

Open Access This article is distributed under the terms of the Creative Commons Attribution 4.0 International License (http:// creativecommons.org/licenses/by/4.0/), which permits unrestricted use, distribution, and reproduction in any medium, provided you give appropriate credit to the original author(s) and the source, provide a link to the Creative Commons license, and indicate if changes were made.

\section{References}

Augustyn M (2004) Anthropogenic changes in the environmental parameters of the Bieszczady mountains. Biosph Conserv 6:43-53

Birks HH, Birks HJB, Kaland PE, Moe D (eds) (1999) The cultural landscape, past, present, future. Cambridge University Press, Cambridge

Bowen ME, McAlpine CA, House APN, Smith GC (2007) Regrowth forests on abandoned agricultural land: a review of their habitat values for recovering forest fauna. Biol Conserv 140:273-296

Ceauşu S, Hofmann M, Navarro LM, Carver S, Verburg PH, Pereira HM (2015) Mapping opportunities and challenges for rewilding in Europe. Conserv Biol 29:1017-1027

Dimbleby GW (1984) Anthropogenic changes from neolithic through medieval times. New Phytol 98:57-72

Drent RH, Prins HHT (1987) The herbivore as prisoner of its food supply. In: van Andel J, Baker JP, Snaydon RW (eds) Disturbance in grasslands, causes, effects and processes. Junk Publishers, Dordrecht, pp 131-147

Estel S, Kuemmerle T, Alcantara C, Levers C, Prishchepov A, Hostert P (2015) Mapping farmland abandonment and recultivation across Europe using MODIS NDVI time series. Remote Sens Environ 163:312-325

Falcucci A, Maiorano L, Boitani L (2007) Changes in landuse/land-cover patterns in Italy and their implications for biodiversity conservation. Landsc Ecol 22:617-631

Feranec J, Jaffrain G, Soukup T, Hazeu G (2010) Determining changes and flows in European landscapes 1990-2000 using CORINE land cover data. Appl Geogr 30:19-35

Gordon IJ (2009) What is the future for wild, large herbivores in human modified agricultural landscapes? Wildlife Biol 15:1-9

Hofman-Kamińska E, Kowalczyk R (2012) Farm crops depredation by European bison (Bison bonasus) in the vicinity of forest habitats in northeastern Poland. Environ Manage 50:530-541

Iverson LR (1988) Land-use changes in Illinois, USA: the influence of landscape attributes on current and historic landuse. Landsc Ecol 2:45-61

Klich D, Olech W, Łopucki R, Danik K (2018) Community attitudes to the European bison Bison bonasus in areas where its reintroduction is planned and in areas with existing populations in northeastern Poland. Eur. J. Wildl 64:61

Kuemmerle T, Levers C, Bleyhl B, Olech W, Perzanowski K, Reusch C, Kramer-Schadt S (2018) One size does not fit all: european bison habitat selection across herds and spatial scales. Landsc Ecol 33:1559-1572

Kuemmerle T, Perzanowski K, Chaskovskyy O, Ostapowicz K, Halada L, Bashta AT, Radeloff VC (2010) European bison habitat in the Carpathian Mountains. Biol Conserv 143:908-916

Marszałek E, Perzanowski K (2018) Wisents from the land of poloniny. Ruthenus, Krosno

Perzanowski K, Gula R (eds) (2002) Proc. International Workshop: Initiation of the transboundary network for monitoring the population status of ungulate species along Polish-Slovak-Ukrainian Carpathians" November 2002, Ustrzyki Dolne, Poland

Perzanowski K, Januszczak M, Wołoszyn-Gałęza A (2011) Utilisation of the terrain by wisents in Bieszczady Mountains. Eur Bison Conserv Newsl 4:5-12

Putman R (1988) The natural history of deer. Comstock Publ Associates, Michigan

Statistical Office in Rzeszow (2018) Regional statistics. Rzeszow, Poland

Tan PN, Steinbach M, Karpatne A, Kumar V (2019) Introduction to data mining, 2nd edn. Pearson Education India, Tharamani

Vera FWM (2000) Grazing ecology and forest history. CABI Publ, Wallingford-NY

Wołoszyn-Gałęza A, Perzanowski K, Januszczak M, Pagacz S (2016) Habitat preferences of a European bison (Bison bonasus) population in the Carpathian Mountains. Ann Zool Fennici 53:1-18

Wulf M, Sommer M, Schmidt R (2010) Forest cover changes in the Prignitz region (NE Germany) between 1790 and 1960 in relation to soils and other driving forces. Landsc Ecol 25:299-313

Zgłobicki W, Gawrysiak L, Baran-Zgłobicka B, Telecka M (2016) Long-term forest cover changes, within an agricultural region, in relation to environmental variables, Lubelskie province, Eastern Poland. Environ Earth Sci 75:1373

Ziółkowska E, Perzanowski K, Bleyhl B, Ostapowicz K, Kuemmerle T (2016) Understanding unexpected reintroduction outcomes: why aren't European bison colonizing suitable habitat in the Carpathians? Biol Conserv 195:106-117

Publisher's Note Springer Nature remains neutral with regard to jurisdictional claims in published maps and institutional affiliations. 